Bojana Jokanović ${ }^{1}$ Andrea Okanović ${ }^{2}$ Bojan Lalic ${ }^{3}$
JEL: M10, D23, L20

DOI:10.5937/industrija46-17740

UDC: 005.94

005.336.1:334.7(497.113)

Original Scientific Paper

\title{
Knowledge Management Diagnosis in Vojvodina Firms by Using Bukowitz and Williams Model
}

\author{
Article history: \\ Received: 6 July 2018 \\ Sent for revision: 6 August 2018 \\ Received in revised form: 15 October 2018 \\ Accepted: 15 October 2018 \\ Available online: 28 December 2018
}

\begin{abstract}
The main purpose of this paper is to empirically analyse the state of knowledge management (KM) practice in one particular region. In order to access the state of Vojvodina firms regarding the applicability of KM program, the Knowledge Management Diagnostic model was applied. Hypotheses based on the specific integrated set of KM were established and statistically tested on a sample of 190 Vojvodina companies from various industries, government institutions and public enterprises. Survey methodology was used with the aim to gather data about KM practice and other related organizational aspects. Our findings show the extent to which individual steps of KM at the whole sample deviate from the maximum value assigned. This survey provides a foundation for practicing engineering managers to position company and recognize the steps of KM that can be improved in order to achieve strategic value and close the gap between the average and maximum value assigned to each step.
\end{abstract}

Keywords: knowledge management models; knowledge management process model; knowledge management diagnostic; Vojvodina.

\footnotetext{
${ }^{1}$ University of Novi Sad, Faculty of Technical Sciences, Serbia, email: bojanajokanovic@uns.ac.rs.

${ }^{2}$ University of Novi Sad, Faculty of Technical Sciences, Serbia

${ }^{3}$ University of Novi Sad, Faculty of Technical Sciences, Serbia 
Jokanović B., et al: Knowledge Management Diagnosis in Vojvodina Firms by Using...

\section{Utvrđivanje stanja menadžmenta znanja u organizacijama na području Vojvodine korišćenjem modela Bukovic i Vilijams}

Apstrakt: Osnovna svrha ovog rada je da empirijski analizira stanje menadžmenta znanja (KM) u jednom određenom regionu. $U$ cilju procene stanja preduzeća u Vojvodini u pogledu primene KM programa, primenjen je dijagnostički model upravljanja znanjem. Hipoteze zasnovane na specifičnom integrisanom setu KM su definisane i statistički testirane na uzorku od 190 vojvođanskih kompanija iz različitih industrija, državnih institucija i javnih preduzeća. Korišćen je metod anketiranja u cilju prikupljanja podataka o praksi KM i drugim srodnim organizacijskim aspektima. Rezultati istraživanja pokazuju stepen do kojeg pojedinačni koraci KM na celom uzorku odstupaju od maksimalne dodeljene vrednosti. Ovo istraživanje pruža osnovu za prakticiranje inženjerskih menadžera da bi lakše pozicionirali kompaniju $i$ prepoznali korake KM koji se mogu poboljšati kako bi se postigla strateška vrednost i zatvorio jaz između prosečne i maksimalne vrednosti dodijeljene za svaki korak.

Ključne reči: modeli upravljanja znanjem; procesni model upravljanja znanjem; dijagnoza upravljanja znanjem; Vojvodina.

\section{Introduction}

Vojvodina, which includes 45 municipalities and towns, is one of the most important regions in Serbia, particularly considering its role in the development of a knowledge-based economy (KBE). The government of the Autonomous Province of Vojvodina invests significant resources in education system and technology in order to improve knowledge-intensive economic activities, especially in the software industry. Yet, little is known how Vojvodina firms react to this new knowledge-based economic development. In particular, there are deficiencies in the literature, so how Vojvodina firms manage knowledge in their organizations as they strive to achieve their competitive performance.

The success of today's companies is largely based on their ability to implement organizational change and modify their principles of work as quickly as possible when their environment starts to change. Knowledge is the main strategic resource for achieving competitive advantage in such an unstable environment, and from a practical perspective, managers, who would like to improve performance and promote a better working environment, should demonstrate their commitment to learning, and thus foster education for the development of a knowledge-based economy. 
Jokanović B., et al: Knowledge Management Diagnosis in Vojvodina Firms by Using...

Knowledge is personified and strongly related to the human factor. People, not the enterprise are the main carrier of knowledge (Dąbrowska-Paulewicz, Wacowska \& Bokwa, 2014). In organizations employee's knowledge potential is a determining factor of survival in competitive environments. A number of authors show that organizations must manage and control their knowledge resources, in order to survive in a complex and competitive environment (Dayan, Heisig, \& Matos 2017).

Knowledge management (KM) includes strategies, processes, and practices that give opportunities to an organization to capture, share, store, access, and use knowledge. Perfect KM integrates different sources of knowledge to support innovation and improve company performance (Sibbald, Wathen \& Kothari, 2016).

The key ingredient, knowledge might require, is measurement and selection of appropriate methods and management techniques, in order to know its true value (Toszewska-Czerniej, 2015).

Although some models are presented in this research, only the Knowledge Management Diagnostic (KMD) model developed by Bukowitz and Williams (1999) was applied. This model provides a practical approach to knowledge management, as well as a framework and quick reference to specific areas of the knowledge management process; from information gathering to facilitating internal knowledge sharing and measuring the organization's knowledge assets. Using the KMD, engineering managers should be able to identify the critical knowledge management process.

In order to access the state of Vojvodina firms regarding the applicability of their knowledge management program, the above mentioned method was applied. Also, in order to improve the development of education in the Vojvodina region, the current state of knowledge management has been analysed. Thus, the state of knowledge management in Vojvodina is determined on a sample of 190 respondents using a questionnaire technique on the basis of the applied method in the empirical part of the paper.

\section{Theoretical Background}

Knowledge is recognized as a critical and main strategic resource for sustained competitive advantages (Kim, Yu, \& Lee, 2003; Magnier-Watanabe, Benton \& Senoo, 2011; Palacios-Marqués, Peris-Ortiz \& Merigo, 2013, Dayan et al., 2017, Gao \& Bernard, 2018). Knowledge management, as a new discipline, becomes a main challenge to a company (Anantatmula \& Kanungo, 2006; Darroch, 2003; Palacios, Gil \& Garrigos, 2009). On the way to a knowledge-based society, organizations are increasingly facing the challenge 
Jokanović B., et al: Knowledge Management Diagnosis in Vojvodina Firms by Using...

to collect and mobilise knowledge resources for creating value (Hislop, Bosua \& Helms, 2018). In the field of business administration, knowledge management is a new discipline. Knowledge management has emerged in areas such as sociology, psychology, pedagogy, artificial intelligence and other cognitive sciences (Bures, 2009).

Davenport and Prusak (1998) viewed knowledge as a combination of experiences, values, contextual information, that offers a framework for evaluation and implementation of new experiences and information.

The effective knowledge management involves learning how to manage knowledge as a subject as well as a process (Choo, 1996; Van den Berg, 2013). Therefore, managers should develop a general understanding of knowledge as well as efficient and systematic method for its management within the organization (Evans, Dalkir \& Bidian, 2014). More knowledge and greater investment in the knowledge management will lead to greater benefits (Reus, Ranft, Lamont \& Adams, 2009).

Some KM studies are focused on culture within organizations (Desouza, 2003; Zack, 1999). However, other studies are focused only on specific activities within the knowledge management process: knowledge acquisition, generation, storage, distribution, application and measurement (Holsapple, \& Joshi, 2002; Mirchandani \& Pakath, 1999; Petrash, 1996; Spiegler, 2003; Szulanski, 1996).

A review of numerous literature sources and empirical research leads to the conclusion that there are several models for assessing the success of knowledge management. This study uses the following: The Spiral Model by Nonaka and Takeuchi (1996); The Wiig Model for Building and Using Knowledge (1993); model of KM developed by Meyer and Zack (1996); The KM Model by Botha (Botha, Kourie \& Snyman, 2014) and Bukowitz and Williams KM Process Model (Bukowitz \& Williams, 2000).

Knowledge management model provides theoretical fundamentals of KM for explaining and describing the best way to manage KM. The most important $\mathrm{KM}$ models are presented below.

\section{Models for Knowledge Management}

In the domain of knowledge management, frameworks and appropriate approaches are widely used to describe the components or technical aspects of design and their interdependence (Hahn \& Subramani, 2000; CEN, 2004; Heisig, 2009). In many cases, the KM frameworks were created to achieve a common understanding of the domain (Bhagat, Kedia, Harveston \& Triandis, 
Jokanović B., et al: Knowledge Management Diagnosis in Vojvodina Firms by Using...

2002; CEN, 2004; Maier, 2004), and to identify gaps in research (Alavi \& Leidner, 2001; Grover \& Davenport, 2001).

Numerous models of knowledge management have been developed by researchers. Leonard-Barton (1995) develops a model that emphasizes the four basic activities that are critical to the development of a knowledge-based organization. Leonard-Barton (1995) focuses on the following activities within the life cycle management of knowledge: the search for creative solutions and their classification; implementation and integration of new technologies and tools into existing processes; introduction of prototypes and pilot projects for the development of skills; importation and acquisition of foreign technology and methodology.

Van der Spek and Spijkervet (1997) observe the cycle of knowledge management as the union of three phases of knowledge management: conceptualize, reflect, act and review of past experiences. Based on the above framework, Lai and Chu (2002) propose a new integrated model that includes: knowledge resources, knowledge management activities and impacts of knowledge.

Some of the most popular models are those suggested by Nonaka and Takeuchi (the spiral model for tacit and explicit knowledge, 1996), the Wiig model of building and using knowledge (1993), model of KM developed by Meyer and Zack (1996), the technology and human focused KM model by Botha (Botha et al. 2014) and the KM process framework by Bukowitz and Williams (2000).

Nonaka and Takeuchi (1996) propose a model of a knowledge creation process (SECl model), in order to understand the dynamic nature of knowledge creation and effectively manage the process. It includes knowledge spiral, which shows how the organization identifies, organizes and systematizes the individual tacit knowledge. It represents a continuous and dynamic interaction between tacit and explicit knowledge.

The process of knowledge creation begins at the individual level. The essence of the model of the knowledge management developed by Nonaka and Takeuchi (1996) is transformation of individual, private and mainly tacit knowledge into public, organizational, useful and easily accessible knowledge. Nonaka and Takeuchi identify four modes of knowledge conversion:

- The process of socialization: from tacit to tacit knowledge.

- The process of externalization: from tacit to explicit knowledge.

- The process of combination: from explicit to explicit knowledge.

- The process of internalization: from explicit to tacit knowledge. 
Jokanović B., et al: Knowledge Management Diagnosis in Vojvodina Firms by Using...

According to Wiig (1993), knowledge should be organized in order to be useful and valuable. It is organized and stored in the form of semantic networks. Wiig's KM model provides some helpful dimensions to organize knowledge: completeness, connectedness, congruency and perspective and purpose. Wiig's model describes each of the four major stages: building, holding, pooling, and applying knowledge. One of the strengths of this model is that knowledge processing is considered at three different levels: individual, group, and organizational level. Another strength of this model is that it provides a more nuanced approach to the classification of knowledge to be managed (Evans, Dalkir \& Bidian, 2014).

Model of knowledge management, which was developed by Meyer and Zack (1996), is derived from the work on the design and development of information products, but it can be successfully applied in the area of intellectual capital. According to this model, phases of the knowledge management cycle are: the acquisition, refinement, storage/retrieval, distribution and presentation or use of knowledge.

The model of knowledge management developed by Meyer and Zack (1996) in terms of the knowledge acquisition and retrieval phase overlaps with Wiig's model. The contribution of this model is reflected in the introduction of the knowledge refinement phase and emphasis on the knowledge distribution, especially through information and communication technologies.

Model of KM developed by Botha et al. (2014) includes three broad categories which overlap and interact with one another: knowledge creation and sensing, knowledge organizing and capturing and knowledge sharing and dissemination. Those three categories are people oriented and technology focused. As particular knowledge management initiative, this model involves the generation of new knowledge.

\section{Knowledge Management Diagnostic (KMD)}

\subsection{The KM Process Model by Bukowitz and Williams}

Models of knowledge management represent a structured way to look at the process of KM used by an organization in order to investigate its properties and customize it to the organization's certain needs.

A variety of $\mathrm{KM}$ models were established. The first widely adopted $\mathrm{KM}$ model was the SECI model, which described how tacit and explicit knowledge can be modified in an organization. Each model has its strengths and weaknesses. But what is missing in other models of $\mathrm{KM}$, and what the $\mathrm{KM}$ process model by Bukowitz and Williams offers is the knowledge divestment, 
Jokanović B., et al: Knowledge Management Diagnosis in Vojvodina Firms by Using...

as well as holistic view of knowledge management. The advantage of this model is in its strategic focus. This model of KM describes the process which determines the strategy for building, divesting and increasing knowledge assets. Also, the advantage is that the CONTRIBUTE process better describes the voluntary nature of knowledge management. Employees must be motivated and encouraged to share what they have learned to a knowledge repository (Evans et al. 2014).

There is no right model of knowledge management, but in this research paper, the KMD process model was used, because of its several advantages:

- It is implemented and verified in real-world settings,

- it is extensive with respect to the various types of steps found in the knowledge management literature,

- it includes detailed descriptions of the knowledge management activities.

- it structures the knowledge management process in the logical stages,

- it provides a valid blueprint for interventions and for getting organizations where they want to be with their knowledge management efforts.

Figure 1. The KM process framework

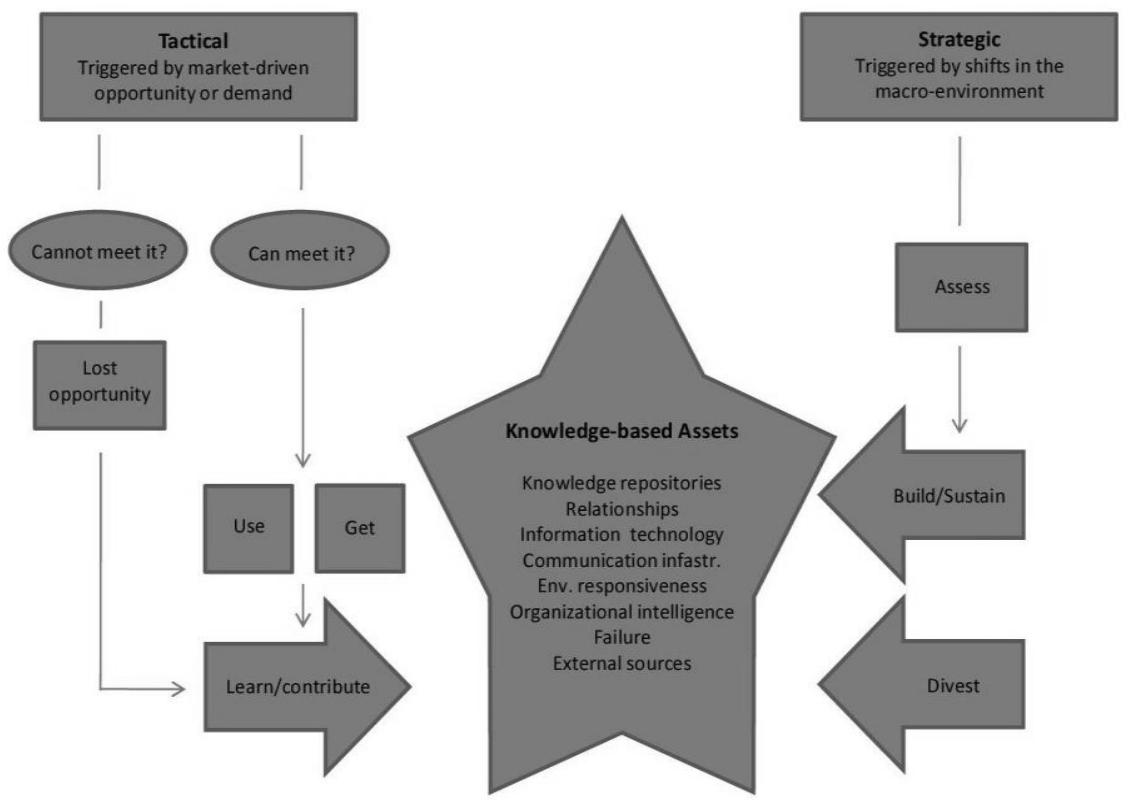

Source: Bukowitz \& Williams (2000)

Industrija, Vol.46, No.4, 2018 
Jokanović B., et al: Knowledge Management Diagnosis in Vojvodina Firms by Using...

Using the process model (KMD) developed by Bukowitz and Williams (Bukowitz \& Williams, 2000), Dihl Horst, de Francisco and Kovaleski (2013) carried out a study in Southern Brazil. Also, Silva, Sicsú and Crisóstomo (2009) applied the KMD method in nine companies. The KMD method was used by Holanda, Dihl and Francisco (2009) to evaluate the performance of knowledge management for an industrial manufacturer of wood panels in Brazil. Tajeddini, Sadat and Shabani (2010) identified and categorized the factors that have an impact on knowledge management implementation in libraries of Shiraz University of Medical Sciences using Bukowitz and Williams model. Bukowitz and Williams (2000) described a knowledge management process framework, which is showed in Fig. 1.

In this framework, knowledge contains knowledge repositories, relationships, information technologies, communication infrastructure, functional skill sets, and process of know-how, environmental responsiveness, organizational intelligence and external sources (Dalkir, 2005). The KMD includes tactical and strategic processes. Tactical part is divided into four sections (get, use, learn and contribute), while strategic part is also divided into four sections (assess, build, sustain and divest).

\subsection{Research Subject, Objectives and Hypotheses}

Given the importance of knowledge management, the purpose of the research was to get a clearer picture and consider the situation in the organizations in Vojvodina regarding the implementation of knowledge management programs based on a review of relevant theoretical and empirical sources.

Based on the necessary steps in the process of knowledge management and using the questionnaire approach, the empirical research was aimed at examining the activities of knowledge management, which, in actual conditions, are considered relevant for specific types of organizations and enable the performances of knowledge management in organizations belonging to various industry segments, varying by size, ownership structure, main business orientation, and origin of capital to be measured. The practical objective of the study was to contribute to the existing knowledge and experience in the field of knowledge management based on the obtained results.

In accordance with the objectives defined in the study the basic hypothesis was set as follows:

- based on the methods applied in the research it is possible to determine the status of knowledge management in the region of Vojvodina. 
Jokanović B., et al: Knowledge Management Diagnosis in Vojvodina Firms by Using...

\subsection{Research Methodology}

The research was conducted using the questionnaire-based method of surveying a representative sample. The questionnaire covered various issues, from the factual issues such as general questions about the organization, through issues related to the respondents' views and opinions. From the total of 44 questions in the questionnaire, the first eight were related to factual, general questions about the organization (legal form, ownership structure, main business orientation, the main activity of the organization, number of employees), 4 questions were personal in nature (gender, age group, education level, position in the organization), while 32 questions were related to the assessment of the current situation in terms of application and the level of development of the concept of knowledge management. Divided into eight segments, each with 4 items analysing the status of specific activities of the process of knowledge management, the third part of the survey assessed knowledge management in the organizations. The questionnaire was based on the Likert scale assessment, with scores from 0 to 5 , consisting of a series of statements regarding the various aspects of a statement. Respondents were asked to assess the extent to which each of the statements in the questionnaire was applicable to the current situation of knowledge management programs in their organizations or organizational units. For each of the 32 individual statements participants were expected to express their level of agreement or disagreement from not applied (0) to fully applied (5).

According to the method developed by Bukowitz and Williams (2000) the framework for measuring the performance of knowledge management consists of tactical and strategic processes. Both processes are divided into four segments whereby getting, using, learning and contributing belong to tactical processes, while assessing, sustaining, building and divesting belong to strategic processes. The following are brief descriptions of steps of knowledge management (Bukowitz \& Williams, 2000)

1. Get - getting knowledge needed to resolve a specific problem;

2. Use - using knowledge to achieve innovative solutions;

3. Learn - reviewing the experiences to generate ideas that influence future results;

4. Contribute - inspiring individuals to share their knowledge;

5. Assess - evaluating the existing knowledge in relation to current and future needs;

6. Sustain - providing support to existing, strategically significant knowledge;

7. Build - developing and distributing new, strategically significant knowledge:

8. Divest - setting aside non-strategic knowledge, and applying it for other positions and tasks. 
Jokanović B., et al: Knowledge Management Diagnosis in Vojvodina Firms by Using...

\subsection{Research Sample}

In cooperation with the Regional Chamber of Commerce Novi Sad, electronic version of the questionnaire is forwarded to a large number of companies (over three thousand). Response rate was unsatisfactory. The printed questionnaire was prepared, in order to increase the number of respondents and to obtain a satisfying research sample.

In order to obtain a highly representative sample, it was selected in a way to represent employees working in organizations which belong to different economic sectors, and differ in size, number of employees and location. The study involved top managers, mid-level managers, operational managers and those who don't belong to managerial position, in selected organizations in Vojvodina region. The survey comprises 190 respondents.

Most of the respondents were from service providing organizations (71.58\%). The share of respondents that come from manufacturing/service providing organizations was $24.21 \%$, while the lowest share was that of the respondents from manufacturing organizations (4.21\%). By examining the structure of the sample in the terms of company ownership, considering the type of the capital, most of the respondents were from organizations in private ownership of a single person and state ownership, with the least of them from organizations with combined ownership structure. Respondents from organizations that were domestic regarding the origin of their capital were by far the most numerous in the whole sample with a share of $91.58 \%$. According to the origin of capital of the ownership structure, respondents from foreign and co-owned organizations were represented equally with $4.21 \%$. The largest number of respondents was from large (over 250 employees) and micro organizations (less than 10 employees), accounting for $34.21 \%$ and $32.63 \%$, respectively. The share of the respondents from small organizations (fewer than 50 employees) in the sample was $24.74 \%$, with the lowest share $(8.42 \%)$ of respondents from medium-sized organizations $(50-250$ employees).

The demographic properties covered in the survey were as follows: respondents' gender, age group, education level and position in the organization. Male respondents accounted for $55.79 \%$, while females accounted for $44.21 \%$ of the whole sample. Respondents were categorized into five age groups based on their age. Most workers in the studied organizations were aged $31-40(28.95 \%)$; they were followed by the respondents from the age group of 20-30 (24.21\%). Respondents of age $41-$ 50 and $51-60$ were equally represented throughout the sample $(22.11 \%)$, while respondents older than 60 were the least represented $(2.63 \%)$. According to their level of education, respondents were categorized into six groups. Respondents with university education were the most numerous in 
Jokanović B., et al: Knowledge Management Diagnosis in Vojvodina Firms by Using...

the whole sample $(42.63 \%)$. They were followed by the respondents with secondary school education (29.47\%), and college education (14.21\%), while the share of those holding $\mathrm{PhD}, \mathrm{MSc}$, or specialist education was $13.69 \%$. According to their position in the organization, respondents were categorized into three groups: top management, mid-level management and operational management (also includes participants who belong to "other"). Regarding the share of the respondents by their position in the organization, more than half of them $(61.05 \%)$ were operational managers and those who don't belong to managerial position, $23.68 \%$ of them belonged to top management, while the share of those coming from mid-level management was $15.26 \%$.

\section{The Research Results}

In measuring the performance of knowledge management we opted for the method developed by Bukowitz and Williams (2000) due to its strategic focus. Thus, using a questionnaire, we assessed the situation regarding the levels of application of the knowledge management concept in the region of Vojvodina.

The maximum number of scores in each step of the process of knowledge management is 20 ( 4 statements $\times 5$ points).

First step: the mean values of steps in the process of knowledge management were calculated by dividing the number of scores obtained by the maximum possible value (20), as shown in the example in Table 1.

Table1. Example of calculating the mean value of each step of the process of knowledge management

\begin{tabular}{|l|c|}
\hline \multicolumn{1}{|c|}{$\begin{array}{c}\text { Step in the process of knowledge } \\
\text { management }\end{array}$} & Result \\
\hline Total scores & 12 \\
\hline Divided by: & 20 \\
\hline = result in percents & $60 \%$ \\
\hline
\end{tabular}

Source: own

Insights obtained using the KMD (Knowledge Management Diagnostic) approach enables managers to develop more successful policies, and tactical and strategic levels in order to increase and improve the overall performance of the organization (Dihl et al., 2013). Drawing on a method developed by Bukowitz and Williams (2000), Table 2 shows the mean values of each step of knowledge management in percentage for the overall sample of 190 respondents in firms in Vojvodina. 
Jokanović B., et al: Knowledge Management Diagnosis in Vojvodina Firms by Using...

Table 2. Values of steps of knowledge management for the overall sample in percentage

\begin{tabular}{|l|c|}
\hline \multicolumn{1}{|c|}{ Activities in the process of knowledge management } & value in $\%$ \\
\hline GET & $78.29 \%$ \\
\hline USE & $65.74 \%$ \\
\hline LEARN & $69.24 \%$ \\
\hline CONTRIBUTE & $71.39 \%$ \\
\hline ASSESS & $70.55 \%$ \\
\hline SUSTAIN & $71.55 \%$ \\
\hline BUILD & $64.55 \%$ \\
\hline DIVEST & $63.39 \%$ \\
\hline
\end{tabular}

Source: own

GET - Based on the obtained results it can be concluded that at the level of the whole sample the respondents can find the knowledge they need; they have the tools they need to find and accept information and have access to resources of information they need to perform their job.

USE - A somewhat lower result has been obtained for the USE activity, compared to the first step of knowledge management. The obtained results indicate the extent to which the physical environment stimulates the exchange of ideas, how well information are reaching all parts of the organization, cooperation with customers and suppliers, and acting on the basis of new ideas.

LEARN - The obtained results for the LEARN step show that organizations from the sample are significantly supporting group activities which encourage mutual learning, discuss the results of successfully performed tasks, treat mistakes as opportunities to learn, and apply the practice of reviewing and reflecting on learned lessons.

CONTRIBUTE - The obtained results for the CONTRIBUTE step of knowledge management refer to the degree to which employees contribute to the growth of organizational knowledge, and include: barriers to knowledge sharing, time required to exchange knowledge, policies of using information obtained from other employees. Therefore, it should be noted that individuals who fail to share their knowledge cannot thrive.

ASSESS - This step of knowledge management examines the extent to which managers recognize knowledge as the primary value-creating resource, whether employees understand how knowledge contributes to the creation of value added for products or services, the existence of formal qualitative and quantitative methods for measuring the process of knowledge management, and the relation between knowledge-flows management and business strategy. 
Jokanović B., et al: Knowledge Management Diagnosis in Vojvodina Firms by Using...

SUSTAIN - The obtained results for the SUSTAIN step indicate that organizations from the sample significantly deliver and provide resources to support existing knowledge. This activity also examines the extent to which the organization protects its critical knowledge, how employees assess the value of knowledge, and whether the organization conducts periodical reviews of experiences with knowledge management and to what extent.

BUILD - The BUILD activity scored lower than the previous steps of knowledge management. Based on the results it appears that at the level of the entire sample of organizations providing resources for the creation of new knowledge it is insufficient. Organizations fail to thoroughly look for the ways to connect with customers and suppliers, and poorly apply processes and rules relating to the construction of new knowledge. This step assesses the policy and cultural standards for rewarding employees.

DIVEST - DIVEST is the lowest scoring activity throughout the whole sample. From the obtained results based on the evaluation of this step it can be concluded that organizations should improve their ability to distinguish between stimulating and useless knowledge, and find ways to divest nonstrategic knowledge or make some alternative use of it.

According to its importance in achieving organizational goals, each step in the process of knowledge management has been assigned a number of scores, so that the total sum of all the activities of the process of knowledge management is 100, as shown in Table 3.

Second step: In order to obtain the average value of each step of the process of knowledge management, their calculated values (described in the first step) are multiplied with the degree of importance (maximum value assigned).

Table 3. Importance of steps of knowledge management in achieving organisational goals and their average value

\begin{tabular}{|l|c|c|}
\hline Activities in the process of knowledge management & Importance & Average value \\
\hline GET & 15 & 11.74 \\
\hline USE & 15 & 9.86 \\
\hline LEARN & 10 & 6.92 \\
\hline CONTRIBUTE & 20 & 14.28 \\
\hline ASSESS & 5 & 3.53 \\
\hline SUSTAIN & 15 & 10.73 \\
\hline BUILD & 15 & 9.68 \\
\hline DIVEST & 5 & 3.17 \\
\hline
\end{tabular}

Source: own

Table 4 shows how the average values of activities examined deviate from the maximum value assigned. In percentages, the deviation of the average values 
Jokanović B., et al: Knowledge Management Diagnosis in Vojvodina Firms by Using...

ranges from the minimum of $21.73 \%$ (GET) to the maximum of $36.6 \%$ (DIVEST).

Table 4. Deviation of average values of steps of knowledge management from the maximum value assigned in percentages

\begin{tabular}{|l|c|}
\hline \multicolumn{1}{|c|}{$\begin{array}{c}\text { Activities in the process of knowledge } \\
\text { management }\end{array}$} & Deviations in percentage \\
\hline GET & $21.73 \%$ \\
\hline USE & $34.26 \%$ \\
\hline LEARN & $30.8 \%$ \\
\hline CONTRIBUTE & $28.6 \%$ \\
\hline ASSESS & $29.4 \%$ \\
\hline SUSTAIN & $28.46 \%$ \\
\hline BUILD & $35.46 \%$ \\
\hline DIVEST & $36.6 \%$ \\
\hline
\end{tabular}

Source: own

Data for all organizations have been processed based on the method developed by Bukowitz and Williams. Thus, a general picture of situation regarding knowledge management in the Vojvodina region has been obtained, as shown in Fig. 2.

Figure 2. Maximum and average value for activities in the process of knowledge management in Vojvodina

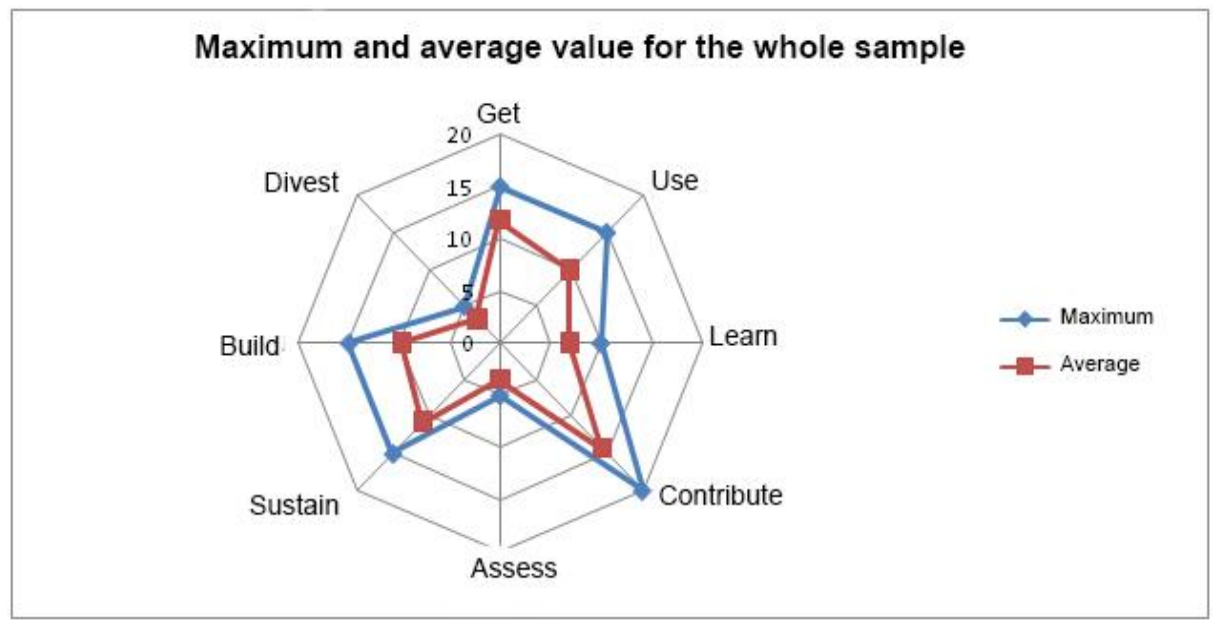

Source: own 
Jokanović B., et al: Knowledge Management Diagnosis in Vojvodina Firms by Using...

The radar chart graphically shows how the group of employees from selected enterprises in Vojvodina assessed the series of organizational activities of the process of knowledge management, as well as the amount of deviation from the maximum assigned and average values of activities. The space between these two forms shows the room available for improving a specific step of the process of knowledge management, as well as the amount of strategic value provided that the organization closes the gap.

In addition to making comparisons with other regions, the results also enable analysing the situation in individual organizations within the region with the aim of comparing the average region-level values. This allows positioning these organizations by the average values of individual activities and maximum possible values.

At the level of the entire sample (190 respondents) the total number of scores for the eight activities of the process of knowledge management is about 70 , out of the maximum 100. The maximum of 100 scores has been found only in one company.

Survey results provide the average state of knowledge management in the region. Also, results enable each company to position itself, regarding the implementation of KM program, within the region, but also within a narrow group. This should be a signal to managers in which way they can improve the processes of knowledge management, and thus the overall performance of the company. Furthermore, managers could detect the sequence of the knowledge management activities, i.e. to notice which process falls behind the most, in relation to the state of knowledge management in the entire region, and to influence first, on that critical activity.

\section{Discussion}

In order to assess the progress of KM initiatives in organisations, different process models have been proposed but a consistent approach that has been empirically tested is lacking. Through the process model of knowledge management (KMD) developed by Bukowitz and Williams (2000) this study successfully recognizes how knowledge is acquired, generated, used, and maintained in companies on the territory of Vojvodina.

Bukowitz and Williams (2000) adopted an acceptable standard for evaluating each step of knowledge management individually from $30 \%$ to $70 \%$, and $66 \%$ for all the steps as a whole. Drawing on the observations and results of these authors, we can conclude that results for each step of knowledge management in this research are within the acceptable standard. However, 
Jokanović B., et al: Knowledge Management Diagnosis in Vojvodina Firms by Using...

some improvements are recommended, especially for DIVEST which is the lowest scoring activity.

Dihl et al. (2013) carried out a study in Southern Brazil using the process model developed by Bukowitz and Williams. Their results have shown that both companies participating in the survey are effective in knowledge management both at tactical and strategic level. The overall results for all the steps of knowledge management were $\mathbf{7 7 . 6 2 \%}$ for the Alpha Company and $74.52 \%$ for the Beta Company.

Tajeddini et al. (2010) concluded that all factors of the Bukowitz and Williams model have an effect on the knowledge management implementation. All of these factors were on a good level, except learning and removing nonstrategic knowledge. The authors suggest that using this tool and programs in healthcare field lead to more successful services and also make easier learning and teaching.

Unlike other models, the process model developed by Bukowitz and Williams offers the possibility of setting aside non-strategic knowledge and strategic focus. Based on the framework offered by Bukowitz and Williams (2000) and the results obtained, our research has proved the practical applicability of the KMD model.

Our findings show the extent to which individual steps of knowledge management at the whole sample of 190 respondents in firms in Vojvodina deviate from the maximum value assigned. The survey provided a general picture of the state of knowledge management in the region.

GET is the highest scoring step of knowledge management among the respondents (deviation from the maximum value assigned: $21.73 \%$ ). Managers working in firms in Vojvodina easily obtain information they need to carry out their tasks and duties. The first phase of the cycle, involves finding information they need for decision making, problem solving and innovation. With modern technology you have access to a growing database of information. However, it is critical to recognize the value of knowledge and that it should be managed efficiently and effectively. The highest deviation has been found for the DIVEST step (deviation from the maximum value assigned: $36.6 \%$ ). The research showed that there is a lack of support for divesting strategically insignificant knowledge which can be used for other tasks and positions. Thus, organization must recognize which knowledge is unnecessary and to encourage a new knowledge. The organization should develop and establish some method to analyse the costs of strategically insignificant knowledge retention. Given the higher deviations obtained for the BUILD (deviation from the maximum value assigned: 35.46 ) and USE (deviation from the maximum value assigned: $34.26 \%$ ) steps of knowledge management, it is recommended that enterprises in Vojvodina should use all 
Jokanović B., et al: Knowledge Management Diagnosis in Vojvodina Firms by Using...

means available to improve the process of developing and launching new knowledge which is strategically significant. Individuals and groups should always look for new experiments, which will contribute to the creation of competitive advantage. The main responsibility of the organization consists of developing and implementing an appropriate action plan for the promotion of new knowledge. The second phase of the cycle - the use of knowledge, deals with the combination of information in a new way to achieve innovative solutions. The organization should ensure such an environment and best practices that will encourage creativity and use of information. The obtained results for the USE step indicate that organizations on the territory of Vojvodina should look for the ways of better motivating employees to apply their knowledge for generating innovative solutions.

It is not difficult, based on the foregoing appraisal, to understand where Vojvodina firms stand in its path towards realization of broad and effective KM capability.

\section{Conclusions}

From a practical perspective, managing knowledge requires a framework, that will help us classify the various types of activities needed to deal with all knowledge-related work within, as well as between organizations (Dalkir, 2005). Processes of knowledge management as described in this research paper can be used by many organizations as a practical framework and instrument for the best practice analysis related to knowledge management.

This survey has pointed out the importance of the concept of knowledge management and measuring its performance. The theoretical and empirical basis provided in the study aimed at initiating and encouraging discussion and criticism both in academic and business communities. But, we still need much more research and experience in the field of knowledge management diagnostic, as interest in application of knowledge management grows. Future research should focus on validating this model in different environments.

Given the importance of knowledge management in the knowledge-based society, we hope that further research will confirm the results obtained in this study about the importance of measuring the performances of knowledge management and provide assistance to organizations in positioning. Companies should ensure processes and systems that encourage cooperation, and free and open flow of information and knowledge through all parts of organization. One of the main advantages of the process model of knowledge management is reflected through the introduction of learning phase where individuals learn from their experiences and an organizational memory is being created. Another advantage of this model is in the inclusion 
Jokanović B., et al: Knowledge Management Diagnosis in Vojvodina Firms by Using...

of the DIVEST step of knowledge management. Thus, the phases of constructing, maintaining and abandoning knowledge represent the decision making point where non-strategic knowledge is either completely abandoned or used for other tasks and positions.

Although knowledge is an important strategic resource which enables organizations to gain and maintain competitive advantage in today's business environment, it seems that knowledge management programs are applied insufficiently. The discipline of knowledge management is theoretically still not rounded up, so the state and company are expected to invest into its development through funding scientific institutions. To involve the knowledge of all levels of management in the process of knowledge management requires increasing the skills and competencies of managers. This raises the organization's efficiency in knowledge management and its competitiveness. Companies should be oriented towards the application of modern management methods and techniques, and learn from the examples of developed and competitive economies, and companies with good business results and practice.

\section{Implications for engineering managers}

A diagnostic model developed by Bukowitz and Williams (2000) is a framework for identifying, analysing and interpreting data in a given context to identify current and desired state of knowledge management.

The results from this research paper can be of use for practicing engineering managers in several ways. First of all, we argue that more attention should be paid to the knowledge management program and its implementation. Second, having in mind the fact that organizations in region of Vojvodina are moving from negotiated to market economy this survey provides a foundation which can be applied by practicing engineering managers to position organization and recognize the steps of knowledge management that can be improved in order to achieve strategic value and close the gap between the average and maximum value assigned to each step. Third, a general guideline for practicing engineering managers interested in improving knowledge management activities is not to focus on the knowledge. Instead, they should pay attention to improving the working environment in which knowledge is created, shared and applied. If specific organizational conditions are properly established by managers, the knowledge based firms will significantly be improved and more successfully utilized, pulling away whole region in desired direction. 
Jokanović B., et al: Knowledge Management Diagnosis in Vojvodina Firms by Using...

\section{References}

Alavi, M., \& Leidner, D.E. (2001). Review: Knowledge Management and Knowledge Management Systems: Conceptual Foundations and Research Issues. MIS Quarterly, 25(1), 107. doi:10.2307/3250961.

Anantatmula, V., \& Kanungo, S. (2006). Structuring the underlying relations among the knowledge management outcomes. Journal of Knowledge Management, 10(4), 25-42. doi:10.1108/13673270610679345.

Barton, D.L. (1995). Wellsprings of knowledge. Boston: Harvard Business School Press.

Bhagat, R.S., Kedia, B.L., Harveston, P.D., \& Triandis, H.C. (2002). Cultural Variations in the Cross-Border Transfer of Organizational Knowledge: An Integrative Framework. Academy of Management Review, 27(2), 204-221. doi:10.5465/amr.2002.6588000.

Botha, A., Kourie, D., \& Snyman, R. (2014). Coping with continuous change in the business environment. Knowledge management and knowledge management technology. Elsevier.

Bukowitz, W.R., \& Williams.R.L., (2000). The knowledge management fielbook. London: Financial Times Prentice Hall..

Bures, V. (2009). Konceptuální perspektiva znalostního managementu. $E_{+} M$ Economics and Management, 12, 84-96.ISSN: 1212-3609. Retrieved from: http://www.ekonomiemanagement.cz/download/1331826713 933d/06 bures.pdf.,

-CEN. (2004). CEN CWA 14924 European Guide to good Practice in Knowledge Management. Brussels. Part 1 to 5, Retrieved from: http://www.fraserhealth.ca/media/Euro\%20Guide\%20to\%20good\%20practice\%2 0in\%20KM\%20Part\%201.pdf..

Choo, C.W. (1996). The knowing organization: How organizations use information to construct meaning, create knowledge and make decisions. International journal of information management, 5(16), 329-340. doi:10.1016/0268-4012(96)00020-5

Dąbrowska-Paulewicz, S., Wacowska, A., \& Bokwa, M. (2014). Personal and professional development as a value in a knowledge-based society. Polish Journal of Management Studies, 9, 14-22. Retrieved from: yadda.icm.edu.pl/yadda/.../c/Dabrowska-Paulewicz.pdf.

Dalkir, K. (2005). Knowledge management in theory and practice. Elsevier Butterworth-Heinemann publications.

Darroch, J. (2003). Developing a measure of knowledge management behaviors and practices. Journal of Knowledge Management, 7(5), 41-54. doi:10.1108/13673270310505377

Davenport, T.H., \& Prusak, L. (1998). Working knowledge: How organization manage what they know. Boston, MA: Harvard Business School Press.

Dayan, R., Heisig, P., \& Matos, F. (2017). Knowledge management as a factor for the formulation and implementation of organization strategy. Journal of Knowledge Management, 21(2), 308-329. doi: 10.1108/jkm-02-2016-0068.

Desouza, K.C. (2003). Strategic contributions of game rooms to knowledge management: some prelimenary insights. Information \& Management, 41(1), 6374. doi:10.1016/s0378-7206(03)00027-2 
Jokanović B., et al: Knowledge Management Diagnosis in Vojvodina Firms by Using...

Dihl, W., Horst, D.J., de Francisco, A.C., \& Kovaleski, J.L. (2013). A diagnosis of knowledge management measuring Incubated companies's performance: A study case. African Journal of Business Management, 7(26), 1993-8233. doi:10.5897/AJBM2012.1373

Evans, M., Dalkir, K., \& Bidian, C. (2014). A holistic view of the knowledge life cycle: The knowledge management cycle (KMC) model. The Electronic Journal of Knowledge Management, 12(2), 85-97. Retrieved from: http://www.ejkm.com/..

Gao, J., \& Bernard, A. (2018). An overview of knowledge sharing in new product development. The International Journal of Advanced Manufacturing Technology, 94(5-8), 1545-1550. doi: 10.1007/s00170-017-0140-5.

Grover, V., \& Davenport, T.H. (2001). General Perspectives on Knowledge Management: Fostering a Research Agenda. Journal of Management Information Systems, 18(1), 5-21. doi:10.1080/07421222.2001.11045672

Hahn, J., \& Subramani, M.R. (2000). A framework of knowledge management systems: Issues and challenges for theory and practice. In Proceedings of the twenty-first international conference on information systems, Brisbane, Australia. (pp. 302-312). Brisbane, Australia.

Heisig, P. (2009). Harmonisation of knowledge management - comparing $160 \mathrm{KM}$ frameworks around the globe. Journal of Knowledge Management, 13(4), 4-31. doi:10.1108/13673270910971798.

Hislop, D., Bosua, R., \& Helms, R. (2018). Knowledge management in organizations: A critical introduction. Oxford University Press.

Holanda, L.M.C., Dihl, W., \& Francisco, A.C. (2009). O perfil da produção científica em gestão do conhecimento: análise dos artigos do Simpósio de Excelência em Gestão e Tecnologia (SEGET). In: SIMPÓSIO DE EXCELÊNCIA EM GESTÃO E TECNOLOGIA. 1-20.

Holsapple, C.W., \& Joshi, K.D. (2002). Knowledge manipulation activities: results of a Delphi study. Information \& Management, 39(6), 477-490. doi:10.1016/s03787206(01)00109-4

Kim, Y., Yu, S., \& Lee, J. (2003). Knowledge strategy planning: methodology and case. Expert Systems with Applications, 24(3), 295-307. doi:10.1016/s09574174(02)00158-6

Lai, H., \& Chu, T.H. (2002). Knowledge management: a review of industrial cases. Journal of Computer Information Systems, 42(5), 26-39. doi:10.1109/hicss.2000.926705

Magnier-Watanabe, R., Benton, C., \& Senoo, D. (2011). A study of knowledge management enablers across countries. Knowledge Management Research \& Practice, 9(1), 17-28. doi:10.1057/kmrp.2011.1

Maier, R. (2004). Knowledge management systems: Information and communication technologies for knowledge management. Aufl., Berlin [ua].

Meyer, M., \& Zack, M. (1996). The design and implementation of information products. Sloan Management Review, 37(3), 43-59. Retrieved from: https://sloanreview.mit.edu/article/the-design-and-development-of-informationproducts/.

Mirchandani, D., \& Pakath, R. (1999). Four models for a decision support system. Information \& Management, 35(1), 31-42. doi:10.1016/s03787206(98)00074-3

Nonaka, I., \& Takeuchi, H. (1996). The knowledge-creating company: How japanese companies create the dinamics of innovation. Long range planning, 4(29), 592. 
Jokanović B., et al: Knowledge Management Diagnosis in Vojvodina Firms by Using...

Palacios, D., Gil, I., \& Garrigos, F. (2009). The impact of knowledge management on innovation and entrepreneurship in the biotechnology and telecommunications industries. Small Business Economics, 32(3), 291-301. doi:10.1007/s11187-0089146-6

Palacios-Marqués, D., Peris-Ortiz, M., \& Merigó, J.M. (2013). The effect of knowledge transfer on firm performance: An empirical study in knowledge-intensive industrie. Management Decision, 51(5), 973-985. doi:10.1108/md-08-2012-0562

Petrash, G. (1996). Dow's journey to a knowledge value management culture. European Management Journal, 14(4), 365-373. doi:10.1016/02632373(96)00023-0

Reus, T.H., Ranft, A.L., Lamont, B.T., \& Adams, G.L. (2009). An Interpretive Systems View of Knowledge Investments. Academy of Management Review, 34(3), 382400. doi:10.5465/amr.2009.40631556

Sibbald, S.L., Wathen, C.N., \& Kothari, A. (2016). An empirically based model for knowledge management in health care organizations. Health Care Management Review, 41(1), 64-74. doi:10.1097/hmr.0000000000000046

Silva, R.J., Sicsú, A.B., \& Crisóstomo, A.P. (2009). Identification of processes knowledge - study multicases in APL footwear Campina Grande. Industrial Management Magazine, Special edition, 5(2). ISSN: 1808-0448.10.3895/S180804482009000300011S1..

Spiegler, I. (2003). Technology and knowledge: bridging a "generating" gap. Information \& Management, 40(6), 533-539. doi:10.1016/s03787206(02)00069-1

Szulanski, G. (1996). Exploring internal stickiness: Impediments to the transfer of best practice within the firm. Strategic Management Journal, 17(S2), 27-43. doi:10.1002/smj.4250171105

Tajeddini, O., Sadat, M. A., \& Shabani, A. (2010). Knowledge management in the era of web 2.0: An evolutionary approach. Jornal of Academic Librarianship and Information Research, 44(51), 101-119.

Toszewska-Czerniej, W. (2015). Knowledge management model. Polish Journal of Management Studies, 12(2), 180-190. Retrieved from: www.pjms.zim.pcz.pl.

van den Berg, H.A. (2013). Three shapes of organisational knowledge. Journal of Knowledge Management, 17(2), 159-174. doi:10.1108/13673271311315141

van der Spek, R., \& Spijkervet, A. (1997). Knowledge management: Dealing intelligently with knowledge. Knowledge management and its integrative elements, 31-59.

Wiig, K.M. (1993). Knowledge management foundations: Thinking about thinking: How people and organizations create, represent and use knowledge. Arlington, TX: Schema Press.

Zack, M.H. (1999). Developing a Knowledge Strategy. California Management Review, 41(3), 125-145. doi:10.2307/41166000 